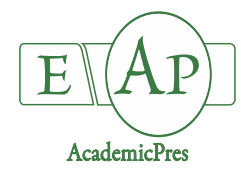

Mkaddem Guedri M et al. (2020)

Notulae Botanicae Horti Agrobotanici Cluj-Napoca 48(4):1929-1940

DOI: $10.15835 / 48412145$

Research Article

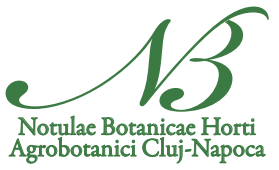

\title{
Chemical composition and antimicrobial and antioxidant activities of Tunisian, France and Austrian Laurus nobilis (Lauraceae) essential oils
}

\author{
Mounira MKADDEM GUEDRI ${ }^{1 *}$, Mehrez ROMDHANE ${ }^{1}$, \\ Ahmed LEBRIHI ${ }^{2}$, Florence MATHIEU ${ }^{2}$, Jalloul BOUAJILA ${ }^{2}$ \\ ${ }^{1}$ Université de Gabès, Ecole National d'Ingénieurs de Gabès, Laboratoire d'Environnement, Catalyse et Analyse des Procédés, Rue \\ Omar elkhattab-ZRIG-6029 Gabès, Tunisie; mounira.mkaddem@gmail.com ("corresponding author); \\ mehrez.romdhane1965@gmail.com \\ ${ }^{2}$ Université de Toulouse, Laboratoire de Génie Chimique, UMR 5503, CNRS, INPT, UPS, Toulouse, France; lebrihi@ensat.fr; \\ florence.mathieu@ensat.fr; jalloul.bouajila@univ-tlse3.fr
}

\begin{abstract}
Essential oil (EO) of Laurus nobilis, from Tunisian, France and Austrian were screened for their chemical composition, antioxidant and antimicrobial activities and compared. GC-MS analysis showed that leaves of Tunisian L. nobilis had camphor (34.43\%), 1,8-cineole (20.21\%) and $\alpha$-terpineol (7\%) as major components. France and Austrian EOs had a high content of 1,8-cineole (45.8\% and 43.4\%, respectively) followed by bornyl acetate ( $13.8 \%$ and $17.7 \%$ respectively) and methyl eugenol (7.7\% and $10.9 \%$ respectively). Antioxidant potential was measured by ABTS and DPPH tests. Tunisian L. nobilis EO showed greater radical scavenging by ABTS activity $\left(\mathrm{IC}_{50}=44.8 \pm 0.1 \mathrm{mg} / \mathrm{L}\right)$ than the France and Austrian EOs $(76.4 \pm 3.2 \mathrm{mg} / \mathrm{L}$ and $81.4 \pm 4.0 \mathrm{mg} / \mathrm{L}$, respectively). However, for DPPH test system, French and Austrian EOs activities were excellent $\left(\mathrm{IC}_{50}=176.1 \pm 5.1 \mathrm{mg} / \mathrm{L}\right.$ and $236.3 \pm 2.9 \mathrm{mg} / \mathrm{L}$ respectively) then Tunisian L. nobilis EO $\left(\mathrm{IC}_{50}=2859.7 \pm 99.0 \mathrm{mg} / \mathrm{L}\right)$. A good Antimicrobial activity was observed on the yeasts and fungi for all EOs. Tunisian laurel EO show a better antibacterial activity against gram-negative bacteria (Klebsiella pneumonial, E. coli and Salmonella enterica CMI: $0.004 \mathrm{mg} / \mathrm{ml}$ ) than gram-positive ones (Bacilus subtilis, Staphylococcus aureus and Listeria monocytogenes CMI: $0.01 \mathrm{mg} / \mathrm{ml}$ ). A significant antifungal activity of Tunisian EO was also observed against fungi and yeasts species (CMI: $0.004 \mathrm{mg} / \mathrm{ml}$ ). France essential oil shows better activities against all organisms tested wail Austrian oil activity is more important against yeasts species tested and Mucor ramannianus (fungi). Chemical composition, antimicrobial and antioxidant activity of Tunisian L. nobilis essential oil, were different from that of France and Austrian and it give the opportunity for its uses in new pharmaceuticals and natural therapies of infectious diseases.
\end{abstract}

Keywords: antioxidant activity; antimicrobial activity; DPPH and ABTS, essential oil; GC-MS; Laurus nobilis

\section{Introduction}

Laurus nobilis (Lauraceae) is cultivated in temperate parts of the world, mainly in south Europe and Mediterranean area. It is more used as flavouring in the culinary preparations. Specie was reputed for his 
ownership particularly stimulating and sedative analgesic (Arvy and Galloin, 2003). The essential oil obtained from the leaves of this plant has been used for relieving haemorrhoid and rheumatic pains (Zargari, 1990). It also has diuretic (Zargari, 1990), healing (Nayak et al., 2006), antifungal (Hassiotis, 2010) and antibacterial (Seyed et al., 1991; Bouzouita et al., 2003) activities which are interesting and useful for food preservation (Brahmi et al., 2015). Nevertheless, species became rare in Tunisia and subsist only in some regions of the North West (Pottier Alapetite, 1979).

Many studies of chemical composition of essential oil extracted from different part of plant (steam, leaves, seeds, floral) of $L$. nobilis cultivated from different geographical region in the world was carried (Lawrence, 1983; Anaç, 1986; Pino et al., 1993; Bouzouita et al., 2001; 2009).

Anticonvulsant activity, aflatoxigenic, insecticides and repellent activity of the leaf essential oil was reported in previous works (Sayyah et al., 2002; Erler et al., 2006; Atanda et al., 2007). Antioxidant activity of L. nobilis essential oil was also being studied (Baratta et al., 1998) Therefore, considering the importance of toxicogenetic investigation of plant the possible effects on Central Nervous System of laurel essential oil (Caputo et al., 2017) and cytotoxic and genotoxic potential of the aqueous extract of $L$. nobilis leaves was recently prouved (Silva et al., 2020). Tunisian $L$. nobilis floral buds' oil was evaluated for their antioxidant activity by two methods: $\beta$-carotene bleaching (BCB) test and 2.2-diphenyl- $\beta$-picrylhydrazyl (DPPH) assay (Bouzouita et al., 2009). The antimicrobial properties against some microorganisms (Seyed et al., 1991; Bouzouita et al., 2003; Marzouki et al., 2009) and antifungal activity were reported (Christos and Evanthia, 2011). Quantitative and qualitative changes in Tunisian $L$. nobilis L. leaves essential oil as affected by different drying methods and total fatty acids laurel seed was recently studied (Sellami et al., 2011; Dhifi et al., 2018). Some previous study reports significant antimicrobial activities in Tunisian L. nobilis essential oil (Bouzouita et al., 2003; Marzouki et al., 2009). However, no earlier study reported the comparison of Tunisian essential oil composition in relation with his biological activities with the most commercialised laurel essential oil to better oriented industrials markets.

Here we reported the results of chemical composition, antioxidant, and antimicrobial activity of Tunisian L. nobilis essential oil compared with those of France and Austrian L. nobilis essential oil commercialized. Our objective is to present the Tunisian laurel essential oils as a new natural and effective antioxidant and antimicrobial agent and to study consequences of chemical composition variability associated with concept of chemotype in terms of therapeutic use of essential oils.

\section{Materials and Methods}

\section{Essential oil isolation}

Fresh leaves of $L$. nobilis cultivated species were collected from region of Mannouba, Tunisia. About $100 \mathrm{~g}$ of the fresh leaves of $L$. nobilis was placed in $400 \mathrm{~mL}$ of distilled water and subjected to hydrodistillation for 3 hours, using a Clevenger-type apparatus (British Pharmacopoeia, 1980) (1.5\% yield). Anhydrous sodium sulphate was used to eliminate water traces from essential oil. The essential oil is stored at $+4{ }^{\circ} \mathrm{C}$ until tested and analysed. Condition of culture, extraction method and stockage were the same of that indicated for commercialized essential oils from France and Austrian L. nobilis.

\section{Chemicals used}

All chemicals used were of analytical reagent grade. All reagents were purchased from Sigma-AldrichFluka (Saint-Quentin France).

\section{$G C$ and $G C / M S$ analysis}

The essential oil composition was determined by a VarianStar3400 (Les Ulis, France) Cx gas chromatograph equipped with a flame ionisation detector (FID) and DB-5 (30 m $\times 0.25 \mathrm{~mm}$; film thickness 
$0.25 \mu \mathrm{m})$ capillary column. Oven temperature gradually rose from $60{ }^{\circ} \mathrm{C}$ to $260{ }^{\circ} \mathrm{C}$ with a gradient of 5 ${ }^{\circ} \mathrm{C} /$ minute and 15 minutes isothermal at $260{ }^{\circ} \mathrm{C}$ and finally rose to $340{ }^{\circ} \mathrm{C}$ at $40{ }^{\circ} \mathrm{C} / \mathrm{min}$. Helium (purity 99.99999\%) was used as the carrier gas at $1 \mathrm{~mL} /$ minute. Total analysis time was 57 minutes. $1 \mu$ of diluted sample $(1 / 100$ in petroleum ether, $\mathrm{v} / \mathrm{v})$ was injected in the split mode (ratio 1:10). The injector was operated at $200{ }^{\circ} \mathrm{C}$. Quantitative data were obtained electronically from FID area percent data without the use of correction factors. Peak integration and quantification were performed automatically with Saturn 2100 Workstation software. A checking of the integration of each peak is carried out and corrected manually if necessary.

Essential oil analysis was performed also with GC chromatograph equipped with a Varian Saturn GC/MS/MS 4D mass selective detector in the electron impact mode (70 ev). MS was adjusted for an emission current of $10 \mu \mathrm{A}$ and electron multiplier voltage between 1400 and $1500 \mathrm{~V}$. The trap temperature was $150^{\circ} \mathrm{C}$, and that of the transfer line was $170{ }^{\circ} \mathrm{C}$. Mass scanning was from 40 to $650 \mathrm{amu}$. The components were identified based on the comparison of their Kovats indices (KI), co-injection of standards, MS experimental data with those contained in commercial or literature libraries (NIST 02 version 2.62, Adams, 2001). Alkanes (C5-C24) were used as reference points in the calculation of KI.

GC and GC-MS analysis results are given in Table 1. All determinations were performed in duplicate and averaged.

\section{DPPH radical scavenging activity}

The 1,1-diphenyl-2-picrylhydrazyl free radical (DPPH) quenching ability of plant essential oil was measured according to Blois (1958) with some modifications. $1.5 \mathrm{~mL}$ of various dilutions of samples (extracts or essential oil $[\mathrm{d}=1.1]$ ) were mixed with $1.5 \mathrm{~mL}$ of $0.2 \mathrm{mM}$ methanolic DPPH solution. After an incubation period of 30 minutes at $25^{\circ} \mathrm{C}$, the absorbance at $520 \mathrm{~nm}$ was measured. The wavelength of maximum

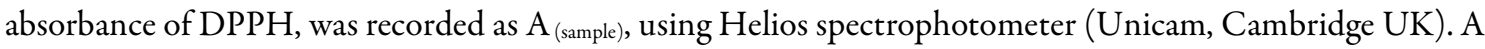
blank experiment was also carried out applying the same procedure to a solution without the test material and the absorbance was recorded as $\mathrm{A}_{\text {(blank). }}$. The free radical-scavenging activity of each solution was then calculated as percent inhibition according to the following equation:

$\%$ inhibition $=\left(\left(\mathrm{A}_{\text {(blank) }}-\mathrm{A}_{\text {(sample })}\right) / \mathrm{A}_{\text {(blank })}\right) \times 100$

Antioxidant activity of standard or samples was expressed as $\mathrm{IC}_{50}$, defined as the concentration of the test material required to cause a 50\% decrease in initial DPPH concentration. Ascorbic acid was used as a standard. All measurements were performed in triplicate.

\section{ABTS radical-scavenging activity}

The ABTS (2, 2'-azinobis-3-ethylbenzothiazoline-6-sulphonate) quenching ability of plant essential oil was determined as described by Re et al. (1999). ABTS was generated by mixing a $7 \mathrm{mM}$ of ABT Sat pH 7.4 (5 $\mathrm{mM} \mathrm{NaH}_{2} \mathrm{PO}_{4}, 5 \mathrm{mM} \mathrm{Na}_{2} \mathrm{HPO}_{4}$ and $154 \mathrm{mM} \mathrm{NaCl}$ ) with $2.5 \mathrm{mM}$ potassium persulfate (final concentration) followed by storage in the dark at room temperature for $16 \mathrm{~h}$ before use. The mixture was diluted with ethanol to give an absorbance of $0.70 \pm 0.02$ units at $734 \mathrm{~nm}$ using spectrophotometer (Helios, Unicam, Cambridge UK). For each sample, diluted methanol solution of the essential oil $(100 \mu \mathrm{L})$ could react with fresh ABTS solution $(900 \mu \mathrm{L})$, and then the absorbance was measured $6 \mathrm{~min}$ after initial mixing. Ascorbic acid was used as a standard. A blank experiment was also carried out applying the same procedure to a solution without the test material and the absorbance was recorded as A (blank). The free radical-scavenging activity of each solution was then calculated as percent inhibition according to the following equation:

$\%$ inhibition $=((\mathrm{A}$ (blank) $-\mathrm{A}($ sample $)) / \mathrm{A}($ blank $)) \times 100$

Antioxidant activity of standard or samples was expressed as IC50, defined as the concentration of the test material required to cause a $50 \%$ decrease in initial DPPH concentration. Ascorbic acid was used as a standard. All measurements were performed in triplicate. 


\section{Antimicrobial activity}

Essential oils were individually tested against a panel of microorganisms (Table 1). Six bacteria including three Gram-positive: Bacilus subtilis ATCC 6633 (Bs), Staphyloccocus aureus CIP7625 (Sa) and Listeria monocytogenes Scott A724 (Lm) and three Gram-negative, Escherichia coli ATCC10536 (E coli), Klebsiella pneumonaea CIP8291 (Kp) and Salmonella enterica CIP833 (Se) were used. Two yeasts Sacharomyces cerevisiae ATCC 4226A (Sc) and Candida albicans IPA 200 (Ca) and three fungi Mucor ramannianus ATCC 9314 (Mr), Aspergillus parasiticus CBS 100926(Ap) and Fusarium culmorum NRRL 3288(Fc) were also tested.

All strains were obtained from the Laboratory of Chemical Engineering, Bioprocess Systems Microbial Department of High National School of Agronomy, Toulouse, France.

\section{Discs diffusion method}

The paper disc diffusion method was employed for the determination of essential oil antimicrobial activity (Ennajar et al., 2009). A suspension of the tested microorganism (concentration to $410^{6} \mathrm{cell} / \mathrm{s} / \mathrm{mL}$ ) was spread on nutrient agar. We take $600 \mu \mathrm{L} / 200 \mathrm{~mL}$ for the bacteria and yeasts and $1 \mathrm{~mL} / 200 \mathrm{~mL}$ for the fungi. The filter discs $(9 \mathrm{~mm}$ in diameter) were imbibed with $15 \mu \mathrm{L}$ of essential oil and placed on the inoculated plates. The plates were then covered with parafilm, finely punched to allow the circulation of air without allowing the mites to escape.

Ampicillin and nalidixic acid $(0.5-20 \mathrm{mg} / \mathrm{L})$ were used as positive reference standards to determine the sensitivity of Gram-positive, Gram-negative bacterial species tested, respectively. Nystatin $(0.5-20 \mathrm{mg} / \mathrm{L})$ was used as positive reference standards to determine the sensitivity of fungi and yeasts species.

After staying at $4{ }^{\circ} \mathrm{C}$ for $2 \mathrm{~h}$, plates were incubated for $48 \mathrm{~h}$ (at $37^{\circ} \mathrm{C}$ for bacteria and at $30^{\circ} \mathrm{C}$ for yeasts and fungus). Antimicrobial activity was evaluated by measuring the zone of inhibition (in millimeters) against the test organism. Tests were carried out in triplicate. Values are presented as means \pm SD of three parallel measurements.

Oils minimal inhibitory concentration (MIC) values were determined based on the agar dilution method. 15 concentrations of each essential oil were essayed $(0.5,1,2,3,4,5,10,15,20,30,40$ and $50 \mu \mathrm{L} / \mathrm{mL})$. The dilutions of essential oils were prepared in the methanol, the Tween 80 to $10 \%$ and $3 \mathrm{~mL}$ of nutrition's solid media. Bacterial suspensions of $10^{6} \mathrm{bac} / \mathrm{mL}$ and of $10^{5}$ of yeasts and fungi were prepared and $1 \mu \mathrm{L}$ was deposed on the solid environments already inoculated by the various microorganisms' tests and then incubated for $48 \mathrm{~h}$ (at $37^{\circ} \mathrm{C}$ for bacteria and at $30^{\circ} \mathrm{C}$ for yeasts and fungi). The same concentrations of every witness and of pure methanol were prepared and dissolved in the Tween 80 to $10 \%$ before tested.

\section{Statistical analysis}

All data were expressed as means \pm standard deviations of triplicate measurements. The confidence limits were set at $\mathrm{P}<0.05$. Standard deviations (SD) did not exceed $5 \%$ for most of the values obtained.

\section{Results}

\section{Chemical composition}

Analysis of the Tunisian L. nobilis essential oil revealed forty-two components representing $99.30 \%$ of the total volatiles (Table 1). The main components were oxygenated monoterpenes (73.1\%). Camphor (34.43\%) was the major compound followed by 1,8-cineole (20.21\%), $\alpha$-terpineol (7.19\%), borneol (6.75\%) and $\alpha$-pinene (6.47\%). Monoterpene hydrocarbons represent $10.8 \%$ of the total oil. However, sesquiterpenes hydrocarbons and sesquiterpenes oxygenated presented only by $4.42 \%$ and $2.19 \%$ of total essential oil, respectively (Table 1$)$. 
Mkaddem Guedri M et al. (2020). Not Bot Horti Agrobo 48(4):1929-1940

Table 1. Chemical composition (peak area (\%)) of essential oils from L. nobilis leaves

\begin{tabular}{|c|c|c|c|c|}
\hline Compounds & $\mathrm{KI}$ & Tunisia oil & France oil & Austria oil \\
\hline$\beta$-pinene & 974 & 0.3 & 0.1 & 0.1 \\
\hline$\alpha$-pinene & 936 & 6.5 & 1.7 & 2.0 \\
\hline$\alpha$-fenchene & 951 & 0.5 & - & - \\
\hline camphene & 954 & 0.5 & - & - \\
\hline Sabinene & 976 & 2.7 & 0.3 & 0.3 \\
\hline$\beta$-myrcene & 985 & 0.1 & - & - \\
\hline p-cymene & 1025 & 0.3 & - & - \\
\hline Limonene & 1028 & - & 2.9 & 3.8 \\
\hline$\alpha$-phellandrene & 1030 & - & 0.1 & 0.2 \\
\hline 1,8 -cineole & 1030 & 20.2 & 45.8 & 43.4 \\
\hline eucalyptol & 1038 & 0.5 & - & - \\
\hline$\gamma$-terpinene & 1057 & 0.3 & 0.3 & 0.3 \\
\hline d-terpinene & 1057 & - & 0.1 & 0.1 \\
\hline$\alpha$-terpinolene & 1086 & - & 1.0 & 0.4 \\
\hline Linalool & 1094 & 1.4 & - & - \\
\hline Fenchol & 1108 & 0.1 & - & - \\
\hline$\alpha$-campholenal ${ }^{*}$ & 1128 & 0.2 & - & - \\
\hline cis-verbenol & 1140 & 0.1 & - & - \\
\hline trans-2-menthenol & 1141 & - & 0.1 & 0.1 \\
\hline Camphor & 1143 & 34.4 & - & - \\
\hline$\beta$-terpineol & 1159 & 0.1 & 0.2 & 0.2 \\
\hline Borneol & 1166 & 6.7 & 0.3 & 0.2 \\
\hline pinocarvone & 1168 & 0.3 & - & - \\
\hline terpinen-4-ol & 1178 & 1.6 & 1.7 & 1.3 \\
\hline$\alpha$-terpineol & 1185 & 7.2 & 5.7 & 2.1 \\
\hline verbenone & 1210 & 0.2 & - & - \\
\hline Geraniol & 1242 & - & 0.1 & 0.1 \\
\hline bornyl acetate & 1285 & 5.0 & 13.8 & 17.7 \\
\hline Thymol & 1290 & 0.6 & - & - \\
\hline carvacrol & 1302 & 0.4 & - & - \\
\hline 4-terpenyl acetate & 1340 & - & 1.0 & 0.4 \\
\hline Eugenol & 1350 & 0.1 & 2.8 & 2.9 \\
\hline neryl acetate & 1376 & 0.4 & 0.8 & 0.5 \\
\hline$\alpha$-copaene & 1388 & - & 0.2 & 0.3 \\
\hline$\beta$-elemene & 1389 & 0.1 & 1.5 & 0.8 \\
\hline methyl eugenol & 1406 & 2.0 & 7.7 & 10.9 \\
\hline$\beta$-caryophyllene & 1415 & 0.4 & 0.2 & 1.4 \\
\hline$\beta$-gurjunene & 1432 & 0.3 & - & - \\
\hline terpinyl propionate & 1435 & 0.1 & 3.8 & 3.2 \\
\hline$\alpha$-guaiene & 1440 & - & 0.4 & 0.6 \\
\hline$\alpha$-himachalene & 1450 & 0.1 & 1.3 & 1.1 \\
\hline Ethyltrans-cinnamate & 1460 & - & 0.4 & 0.3 \\
\hline$\gamma$-muurolene & 1480 & 0.2 & 0.2 & - \\
\hline germacrene D & 1480 & 0.2 & - & - \\
\hline$\beta$-selinene & 1482 & 2.6 & 1.7 & 1.0 \\
\hline calamenene* & 1512 & 0.2 & - & - \\
\hline Cubenol & 1514 & 0.3 & - & - \\
\hline$\delta$-cadinene & 1524 & 0.1 & 0.2 & 1.1 \\
\hline$\alpha$-cadinene & 1534 & 0.2 & 0.5 & 0.4 \\
\hline$\beta$-caryophyllene oxide & 1580 & 1.6 & 0.2 & - \\
\hline elemicine $^{*}$ & 1582 & - & 0.7 & 1.1 \\
\hline$\alpha$-cedrol & 1596 & 0.3 & - & - \\
\hline$\beta$-eudesmol & 1650 & - & 1.4 & 0.4 \\
\hline nootkatone* & 1804 & - & 0.2 & - \\
\hline Total & & 99.3 & 99.7 & 98.9 \\
\hline Monoterpene hydrocarbons & & 10.8 & 6.7 & 7.2 \\
\hline Monoterpenes oxygenated & & 73.1 & 54.0 & 47.4 \\
\hline Sesquiterpenes hydrocarbons & & 4.4 & 6.3 & 6.7 \\
\hline Sesquiterpenes oxygenated & & 2.2 & 1,8 & 0.4 \\
\hline Phenolics & & 1.1 & 2.8 & 2.9 \\
\hline Others & & 7.8 & 28.2 & 34.2 \\
\hline
\end{tabular}

*: Tentatively identified supported by good match of MS. -: Not determined. 
Thirty-five components representing 99.7\% of the total volatiles were identified for France L. nobilis essential oil. The main components were oxygenated monoterpenes (54\%). 1,8-cineole (45.8\%) was the major compound followed by bornyl acetate (13.8\%) and methyl eugenol (7.7\%). Monoterpene hydrocarbons represented only $6.7 \%$ of the total, when sesquiterpenes hydrocarbons and sesquiterpenes oxygenated were lowly represented (6.3 and $1.8 \%$, respectively) (Table 1 ).

Thirty-one components, representing 98.9\% of the total volatiles, were identified for Austrian L. nobilis essential oil and oxygenated monoterpenes (47.4\%) were the abundant. The prominent component in $L$. nobilis essential oil from Austrian was 1,8-cineole (43.4\%), bornyl acetate (17.7\%) and methyl eugenol (10.9\%). Monoterpene hydrocarbons (7.2\%) and sesquiterpenes hydrocarbons were not mostly present (Table 1).

\section{Antioxidant activity}

We have investigated free radical scavenging activity, of the three L. nobilis essential oils by ABTS assay (Table 2). The ABTS was not tested for L. nobilis leaves. Tunisian L. nobilis essential oil (mixture of compounds) included a high activity $\left(\mathrm{IC}_{50}=44.8 \pm 0.1 \mathrm{mg} / \mathrm{L}\right)$ to scavenge $\mathrm{ABTS}$ radical cation comparing with standards $(1.9 \pm 0.1 \mathrm{mg} / \mathrm{L})$. Although the ABTS radical scavenging activity of France and Austrian essential oils $\left(\mathrm{IC}_{50}=76.4 \pm 3.2 \mathrm{mg} / \mathrm{L}\right.$ and $\mathrm{IC}_{50}=81.4 \pm 4.0 \mathrm{mg} / \mathrm{L}$, respectively) were significant but less important compared to Tunisian essential oil.

Table 2. Antioxidant activity of L. nobilis leaves essential oils

\begin{tabular}{|c|c|c|}
\hline Samples & ABTS IC $_{50}(\mathrm{mg} / \mathrm{L})$ & DPPH IC $_{50}(\mathrm{mg} / \mathrm{L})$ \\
\hline L. nobilis - Tunisia & $44.8 \pm 0.8$ & $2859.7 \pm 99.0$ \\
\hline L. nobilis - France & $76.4 \pm 3.2$ & $176.1 \pm 5.1$ \\
\hline L. nobilis - Austria & $81.4 \pm 4.0$ & $236.3 \pm 2.9$ \\
\hline Vitamin C & $1.9 \pm 0.1$ & $4.4 \pm 0.2$ \\
\hline
\end{tabular}

By DPPH assay, results were in opposition to those obtained with ABTS assay (Table 2). Therefore, Tunisian $L$. nobilis essential oil $\left(\mathrm{IC}_{50}=2859.7 \pm 99.0 \mathrm{mg} / \mathrm{L}\right)$ were feebly active and a moderate antioxidant activity were determined for France $\left(\mathrm{IC}_{50}=176.1 \pm 5.1 \mathrm{mg} / \mathrm{L}\right)$ and Austrian $\left(\mathrm{IC}_{5_{0}}=236.3 \pm 2.9 \mathrm{mg} / \mathrm{L}\right)$ essential oils compared to activity of standard $(4.4 \pm 0.2 \mathrm{mg} / \mathrm{L})$.

\section{Antimicrobial activity}

Antimicrobial activity of $L$. nobilis essential oils was evaluated against 3 Gram-positive bacteria, $3 \mathrm{Gram}$ negative bacteria, 3 fungi and 2 yeasts species by zone diameter (Table 3). These micro-organisms are morphologically and physiologically different.

Tunisian L. nobilis essential oil $(15 \mu \mathrm{L})$ exhibited a great potential for antimicrobial activities against the tow fungi: $M$. ramamnianus ( $43 \mathrm{~mm}$ of inhibition zone) and $A$. parasiticus ( $24 \mathrm{~mm}$ of inhibition diameter) and yeasts species (C.albicans and S. cerevisiae with $26 \mathrm{~mm}$ of inhibition zone) (Table 3 ). The strongest activity for bacterial strains sensitive to Tunisian laurel oil was observed against $S$. aureus (gram+bacteria) with $23 \mathrm{~mm}$ of inhibition zones more than that of antibiotic (Table 3). Activity against B. subtilis and L. monocytogenes (Gram+ bacteria) is moderate and it attends respectively 20 and $17 \mathrm{~mm}$ of inhibition zone. A low sensitivity of $K$. pneumonia and S. enterica (Gram-negative bacteria) (Table 3) comparing with standard one $(10 \mathrm{~mm}$ of inhibition zone). However, E. coli (gram-bacteria) is insensitive to Tunisian L. nobilis essential oil. We can say that Gram positive bacteria are significantly more sensitive to Tunisian Laurus nobilis oil. However, gram negative bacteria are low sensitive to this oil as perhaps their resistance mechanism that manifests itself in the structure of their bacterial envelope (Moghtader and Farahmand, 2013) as well as in their enzymatic arsenals. 
France commercialized essential oil reacted efficiency with fungi microorganisms: $M$. ramamnianus ( 43 $\mathrm{mm}$ of inhibition zone), A. parasiticus (28 mm of inhibition diameter) and F. Culmorum (ZI: $26 \mathrm{~mm}$ ) compared to standard test (Table 3). The maximal inhibition zones for bacterial strains sensitive to the France laurel oil was also $S$. aureus (gram- positive bacteria) (30 mm of inhibition zone $>20 \mathrm{~mm}$ standard zone). Activity against the two others gram positive bacteria as L. monocytogenes (ZI: $20 \mathrm{~mm}$ ) and B. subtilis (ZI: 12 $\mathrm{mm}$ ) are less important. The weakest activity was also observed against gram-negative bacteria (ZI: $10-13 \mathrm{~mm})$ with a feebly sensitivity to E coli (ZI: $10 \mathrm{~mm}$ ). Activity of France laurel oil against yeasts species (ZI: $17-20 \mathrm{~mm}$ ) were relatively low then that of standard and that noted for Tunisian laurel leaves oil.

Important activity of Austrian laurel leaves oil against fungi: $M$. ramamnianus (ZI: $38 \mathrm{~mm}$ ) and $F$. culmorum (ZI: $20 \mathrm{~mm}$ ) are also distinguished compared to standard ( 31 and $24 \mathrm{~mm}$ respectively). However, $A$. parasiticus (fungi) is insensitive to this oil. Yeasts activities were also important then standard ones for $C$. Albicans (with ZI: 35 ) and S. cerevisiae $(23 \mathrm{~mm}$ ).

Table 3. Antimicrobial activity of L. nobilis essential oil

\begin{tabular}{|c|c|c|c|c|}
\hline \multicolumn{5}{|c|}{ Zones of inhibition $(\mathrm{mg} / \mathrm{mL})$} \\
\hline Laurus nobilis & Tunisia & France & Austria & Standards \\
\hline Gram positive bacteria & & & & Ampicillin \\
\hline B. subtilis & 20 & 12 & 17 & 54 \\
\hline S. aureus & 23 & 30 & 23 & 20 \\
\hline L. monocytogenes & 17 & 20 & 16 & 31 \\
\hline Gram negative bacteria & & & & Nalidixic acid. \\
\hline Echerchia coli & 0 & 10 & 10 & 30 \\
\hline$K$.pneumoniae & 10 & 12 & 10 & 28 \\
\hline S. enterica & 10 & 13 & 10 & 28 \\
\hline Yeast & & & & Nystatin \\
\hline S. cerevisiae & 26 & 17 & 23 & 29 \\
\hline C. albicans & 26 & 20 & 35 & 30 \\
\hline Fungi & & & & Nystatin \\
\hline M. ramamnianus & 43 & 43 & 38 & 31 \\
\hline A. parasiticus & 24 & 28 & 0 & 24 \\
\hline F. culmorum & 0 & 26 & 20 & 30 \\
\hline
\end{tabular}

“-": Absence of inhibition zone detected. Essential oil concentration:

$15 \mu \mathrm{L} /$ disc; reference standards concentration: $0.33 \mathrm{mg} / \mathrm{L}$.

The maximal inhibition zones for bacterial strains sensitive to the Austrian oil was also noted for $S$. aureus (gram-positive bacteria) (23 $\mathrm{mm}$ of inhibition zone) while activity against $B$. subtilis and $L$. monocytogenes (ZI: 17 and $16 \mathrm{~mm}$ respectively) are not significant compared to standard ones (25 and 35 $\mathrm{mm})$. Activity against gram-negative bacteria is relatively insignificant as France and Tunisian oils in comparison with standard (ZI: $10 \mathrm{~mm}$ ).

CMI of gram-positive bacteria of Tunisian L. nobilis essential oil was very important $(0.01 \mathrm{mg} / \mathrm{ml})$ compared to standard ones $(0.02 \mathrm{mg} / \mathrm{ml}$ ) and to France and Austrian activities (Table 4$)$ and they confirm result obtained by screening test.

Although gram-negative bacteria tested found to be very sensitive to Tunisian L. nobilis oil (CMI: 0.004 $\mathrm{mg} / \mathrm{ml})$ in comparison with standard test $(0.01$ to $0.02 \mathrm{mg} / \mathrm{ml})$ they present a non-significant screening test. CMI noted for yeasts species (C. albicans and S. cerevisiae) $(0.004$ and $0.005 \mathrm{mg} / \mathrm{ml}$ respectively) and fungi tested (M. ramamnianus and $A$. parasiticus) $(0.003$ to $0.004 \mathrm{mg} / \mathrm{ml})$ proved a stronger activity confirm result obtained by screening test. F. culmorum and E. coliexhibit important value of CMI $(0.004 \mathrm{mg} / \mathrm{ml})$ nevertheless they appeared to be inactive in screening test (Table 3). 
France essential oil exhibited an interesting antimicrobial activity against all microorganisms tested proved by CMI tests $(0.003$ to $0.004 \mathrm{mg} / \mathrm{ml}$ ) (Table 4). These results prove the screening test only for $M$. ramamnianus (fungi) and $S$. aureus (gram-positive bacteria).

Table 4. Antimicrobial activity (MIC $(\mathrm{mg} / \mathrm{mL}))$ of L. nobilis essential oils

\begin{tabular}{|c|c|c|c|c|}
\hline \multicolumn{5}{|c|}{ Zones of inhibition $(\mathrm{mg} / \mathrm{mL})$} \\
\hline Laurus nobilis & Tunisia & France & Austria & Standards \\
\hline Gram-positive bacteria & & & & 0.02 \\
\hline B. subtilis & 0.01 & 0.004 & 0.005 & 0.02 \\
\hline S. aureus & 0.01 & 0.004 & 0.01 & 0.02 \\
\hline L. monocytogenes & 0.01 & 0.004 & 0.01 & Nalidixic acid \\
\hline Gram-negative bacteria & & & & 0.02 \\
\hline Escherichia coli & 0.004 & 0.004 & 0.005 & 0.02 \\
\hline K. pneumoniae & 0.004 & 0.004 & 0.004 & 0.02 \\
\hline S. enterica & 0.004 & 0.004 & 0.01 & 0.02 \\
\hline Yeast & & & & 0.02 \\
\hline S. cerevisiae & 0.005 & 0.004 & 0.004 & Nystatin \\
\hline C. albicans & 0.004 & 0.003 & 0.004 & 0.02 \\
\hline Fungi & & & & 0.02 \\
\hline M. ramamnianus & 0.003 & 0.003 & 0.004 & 0.015 \\
\hline F. culasiticus & 0.004 & 0.004 & 0.01 & 0.004 \\
\hline
\end{tabular}

The antimicrobial properties of essential oils from Austrian were significant also by CMI concentration which ranged from $0.01 \mathrm{mg} / \mathrm{ml}$ (for S. aureus, L. monocytogenes and S. enterica) to $0.005 \mathrm{mg} / \mathrm{ml}$ (B. subtilis and $E$. coli) antifungal activity are also important $(0.004 \mathrm{mg} / \mathrm{ml}$ for $M$. ramamnianus to $0.01 \mathrm{mg} / \mathrm{ml}$ for $A$. parasiticus). These results agree with screening test only for $S$. aureus, $C$. albicans and F. culmorum.

CMI concentration of all microorganisms are relatively effective in comparison with standards ones (Table 4), so we can conclude that essential oil of $L$. nobilis from Tunisian, France and Austrian have a good antimicrobial activity (Table 4).

\section{Discussion}

Tunisian L. nobilis essential oil was richer in terpenes ( 42 components) for the most part by oxygenated monoterpenes (73.1\%) then France (54\%) and Austrian (47.4\%) essential oils. Monoterpene hydrocarbons were also relatively higher in Tunisian laurel oil (10.8\%) then France (6.7\%) and Austrian (7.2\%) ones. In Tunisian laurel oil, camphor is the major component added to 1,8-cineole. This result is original and it make a difference with France and Austrian oil how the 1,8-cineole only is the more represented component. This difference can be attributed to bioclimatic and ecological conditions of three different provenances. camphor has a long tradition of use as antiseptic, antipruritic, rubefacient, abortifacient, aphrodisiac, contraceptive and lactation suppressant (Ashish and Aggarwal, 2007). It has also antifumigant and insecticidal effect (Quintai and Yongcheng (1998). The natural form of camphor (D-camphor) was not harmful (Belzt et al., 2003). A few Studies of pharmacological interactions between camphor and other compounds are present in the literature (Tassell et al., 2010).

L. nobilis leaves essential oils from all over the world were richer in 1,8-cineole (chahal et al., 2017). However, Linool, $\alpha$-terpinol, $\alpha$-terpenyl acetate and thymol were also revealed as major component (chahal et al., 2017). Camphor is present in essential oil of Tunisian Laurus nobilis (Ben Jemâa et al., 2012) bat it was not previously found as a major component. 
Many studies have determined the potential antioxidant activity of various extracts (lives and seeds) (Chahal et al., 2017) but a little information is available about the antioxidant leaves essential oil (Bouzouita et al., 2009; Saab et al., 2012). Antioxidant activities for Tunisian laurel are essayed only in floral buds' essential oil by B-carotene bleaching test and DPPH radical scavenging method (Bouzouita et al., 2009).

In many reports, the antioxidant performance of essential oils was due to the presence of phenolic compounds (Bouzouita et al., 2009; Mkaddem et al., 2010; Ozen et al., 2011 ; Goudjil et al., 2015).The lowest antioxidant activity of Tunisian Laurus nobilis essential oil with DPPH test $\left(\mathrm{IC}_{50}=2859.7 \pm 99.0 \mathrm{mg} / \mathrm{L}\right)$ can be explained by the fact that the phenolic compounds in the essential oils are low (1.1\% of total oil represented by carvacrol, thymol and eugenol).While the ABTS assay involved other anti-radical cationic compounds. The percentage of components with hydroxyl function (aromatic and non-aromatic) in Tunisian L. nobilisessential oil is $21.6 \%$ (Table 1). In fact, especially hydroxyls of tertiary carbon (terpinen-4-ol, linalool, $\beta$-terpineol...) forms a radical presenting an acceptable stability even if it is less stable that the phenolic hydroxyls. In France essential oil, components with hydroxyl function represent $20 \%$ of total essential oil when they represent only $18.1 \%$ in Austrian essential oil (Table 1).

Our sample shows an important variation in the essential oil composition in comparison with other sample from Tunisia due to geographical bioclimatic factors, age of plant and the season of harvest. It represents a new chemotype.

We noted a various antimicrobial activity due to the nature of microorganisms tested and to origins of plants and composition of the essential oil. In general, all laurel oils tested in our work were more active against Gram-positive than Gram-negative bacteria. S. aureus (gram+bacteria) is the most sensitive strain as proved by literature (Derwich et al., 2009) and M. ramamnianus was the most sensitive fungi to laurel oil. However, the most resistant strains were $E$. coli (gram-bacteria). These results are different from those obtained forTunisian laurel leaves essential oil with 1,8 cineole as major component how E. coli was revealed the most sensitive bacteria (Bouzouita et al., 2003).

This is the first study to report activities of $L$. nobilis essential oil against yeasts species. C. albicans and S. enterica $(26 \mathrm{~mm}$ and CMI ringing from 0.004 to $0.005 \mathrm{mg} / \mathrm{ml}$ ) and fungi species $M$. ramamnianus and $A$. parasiticus ( 43 and $24 \mathrm{~mm}$ and CMI of 0.003 and $0.004 \mathrm{mg} / \mathrm{ml}$ respectively). These activities were important and it may be related to major compounds of the essential oil (camphor and 1,8-cineole) or to synergic effect between them. However, 1,8- cineole, has been known to exhibit antimicrobial activity against the bacterial strains (E. coli, P. aeruginosa, S. typhi, Staphylococcus aureus, Staphylococcus intermedius, Bacillus subtilis) (Saab et al., 2012) but there is no previous study that reported the activity of purified camphor components.

\section{Conclusions}

In recent years, the international demand for labelled and certified products is growing. The objectives of this study were: to orient seriously the choice of the essential oils replaying to the requirements of the markets, amplify their usage domains and envisaged conservation and improvement of variety with new specific essential oil composition suitable to pharmaceutical and industries food processing.

The results in this work showed that Tunisian laurel leaf essential oil represented a new chemotype of camphor and 1,8 cineole. Essential oils from France and Austrian were reached by 1,8-cineole. Ecological factors (climatic and soil conditions) have strong influence on the essential oil content (Bisio et al., 1999; Sangun et al., 2007)

A good antioxidant activity to scavenge ABTS radical cation was determined for Tunisian essential oil $\left(\mathrm{IC}_{50}=44.8 \pm 0.1 \mathrm{mg} / \mathrm{L}\right)$. This result is cited for the first time and it gives the opportunity for uses Tunisian $L$. nobilis essential oil in pharmaceuticals industries. Therefore, Tunisian L. nobilis essential oil was feebly active against DPPH radical cation and moderate antioxidant activities were determined for France and Austrian leaves essential oils. 
Tunisian L. nobilis essential oil exhibited a great potential for antimicrobial activities against fungi $(M$. ramamnianus and $A$. parasiticus) and yeasts species (C. albicans and S. cerevisiae). Gram $(+)$ bacteria $(S$. aureus and $B$. subtilis) is more sensitive to all $L$. nobilis essential oil tested then gram (-) ones. This result was proved by screening test and CMI concentration.

France commercialized essential oil shows good activities against fungi (M. ramamnianus). However, sensitivity of gram $(+)$ bacteria (S. aureus and L. monocytogenes) was more important than that of gram (-) ones. Important activity of Austrian leaves essential oil against $F$. culmorum (fungi), $C$. albicans (yeasts) and $S$. Aureus (gram (+) bacteria) are also noted by screening and CMI testes.

Austrian essential oil is similar to Tunisian and France essential oils to inhibit activity of gram $(+)$ bacteria (essentially $S$. aureus) more than antibiotics.

We concluded that Tunisian L. nobilis essential oil has a good activity against fungi, yeasts, and bacteria globally different from France and Austrian commercialized essential oil. This significant difference is probably due to variability in their composition (major and minor components) (Derwich et al., 2009; Dhifi et al., 2018). Results concerning antimicrobial and antioxidant activities of Tunisian L. nobilis were important and different from commercialized essential oil and it give the opportunity to better use Tunisian $L$. nobilis essential oil as a new natural and effective antimicrobial agent in conservation, pharmaceuticals, natural therapies of infectious in human, and management of plant diseases.

\section{Authors' Contributions}

Conceptualization: MR; Visualization, Methodology and Supervision: JB; Methodology and formal analysis AL and FM. All authors read and approved the final manuscript.

\section{Acknowledgements}

This work was supported by Ministry of Higher Education and Scientific Research.

\section{Conflict of Interests}

The authors declare that there are no conflicts of interest related to this article.

\section{References}

Arvy MP, Galloin F (2003). Epices, aromates et condiments. Ed. Belin, pp 412.

Anaç O (1986). Essential oil contents and chemical composition of Turkish laurel leaves. Perfumer and Flavorist 11(5):73-75.

Ashish G, Aggarwal P (2007). Camphor: a lesser-known killer. Southern Medical Journal 100(2):134-135. https://doi.org/10.1097/01.smj.0000254202.13518.f3

Atanda OO, Akpan I, Oluwafemi F (2007). The potential of some spice essential oils in the control of $A$. parasiticus $\mathrm{CFR}$ 223 and aflatoxin production. Food Control 18:601-607. https://doi.org/10.1016/j.foodcont.2006.02.007

Baratta MT, Dorman HD, Deans SG, Biondi DM, Rubeerto G (1998). Chemical composition, antimicrobial and antioxidative activity of laurel, sage, rosemary, oregano and coriander essential oils. Journal of Essential Oil Research 10:618-627. https://doi.org/10.1080/10412905.1998.9700989 
Belz GG, Loew D (2003). Dose-response related efficacy in orthostatic hypotension of a fixed combination of D-camphor and an extract from fresh Crataegus berries and the contribution of the single components. Phytomedicine 10(4):61-67. https://doi.org/10.1078/1433-187X-00303

Ben Jemâa JM, Tersim N, Toudert TK, Khouja ML (2012). Insecticidal activities of essential oils from leaves of Laurus nobilis L. from Tunisia, Algeria and Morocco, and comparative chemical composition. Journal of Stored Products Research 48:97-104.

Bisio A, Corallo A, Gastaldo P, Romussi G, Ciarallo G, Fontana N, ... Profumo P (1999). Glandular hairs and secreted material in Salvia blepharophylla Brandegee ex Epling grown in Italy. Annals of Botany 83:441-452. https://doi.org/10.1006/anbo.1998.0838

Blois MS (1958). Antioxidant determination by use of free radical stable. Nature 181:1199-1200. https://doi.org/10.1038/1811199a0

Bouzouita N, Nafti A, Chaabouni MM, Lognay GC, Marlier M, ... Thonat PH (2001). Chemical composition of Laurus nobilis oil from Tunisia. Journal of Essential Oil Research 13:116-117.

Bouzouita N, Kachouri F, Hamdi M, Chaabouni MM (2003). Antimicrobial activity of essential oils from Tunisian aromatic plants. Flavour and Fragrance Journal 18(5):380-383. https://doi.org/10.1002/ff. 1200

Bouzouita N, El omri A, Kachouri F, Watherlet JP, Marlier M, Chaabouni M (2009). Chemical composition and antioxidant activity of Laurus nobilis floral buds essential oil. Journal of Essential Oil Bearing Plants 12(6):694702. https://doi.org/10.1080/0972060X.2009.10643777

Brahmi N, Scognamiglio M, Pacifico S, Mekhoukhe A, Madani K, Fioentino A, ... Monaco P (2015). ${ }^{1} \mathrm{H}$ NMR based metabolic profiling of eleven Algerian aromatic plants and evaluation of their antioxidant and cytotoxic properties. Food Research International 76(3):334-341. https://doi.org/10.1016/j.foodres.2015.07.005

British Pharmacopoeia (1980). Adsorbed tetanus vaccine. HMSO, London pp 880.

Caputo L, Nazzaro F, Souza LF, Aliberti L, De Martino L, Fratianni F, ... De Feo V (2017). Laurus nobilis: composition of essential oil and its biological activities. Molecules 22:930. https://doi.org/10.3390/molecules22060930

Chahal KK, Kaur M, Bhardwaj U, Singla N, Kaur A (2017). A review on chemistry and biological activities of Laurus nobilis L. essential oil. Journal of Pharmacognosy and Phytochemistry 6(4):1153-1161.

Christos NH, Evanthia, ID (2011). The effects of laurel (Laurus nobilis L.) on development of two mycorrhizal fungi. International Biodeterioration\& Biodegradation 65(4):628-634. https://doi.org/10.1016/j.ibiod.2011.03.006

Derwich E, Benziane Z, Boukir A (2009). Chemical composition and antibacterial activity of leaves essential oil of Laurus nobilis from Morocco. Australian Journal of Basic and Applied Sciences 3(4):3818-3824.

Dhifi W, Bellili S, Jazi S, Ben Nasr S, El Beyrouthy M, Mnif W (2018). Phytochemical composition and antioxidant activity of Tunisian Laurus nobilis. Pakistan Journal of Pharmaceutical Sciences 31(6):2397-2402.

Ennajar M, Bouajila J, Lebrihi A, Mathieu F, Abderraba M, Raies A, Romdhane M (2009). Chemical composition and antimicrobial and antioxidant activities of essential oils and various extracts of Juniperus phoenicea L. (Cupressacees). Journal of Food Sciences 74(7):364-371. https://doi.org/10.1111/j.1750-3841.2009.01277.x

Erler F, Ulug I, Yalcinkaya B (2006). Repellent activity of five essential oils against Culexpipiens. Fitoterapia 77:491-494. https://doi.org/10.1016/j.fitote.2006.05.028

Goudjil MB, Ladjel S, Bencheikh S, Zighmi S, Hamada D (2015). Study of the chemical composition, antibacterial and antioxidant activities of the essential oil extracted from the leaves of Algerian Laurus nobilis (Lauraceae). Journal of Chemistry and Pharmaceutical Research 7(1):379-385. https://doi.org/10.12692/ijb/12.1.187-192

Hassiotis C N (2013). Evaluation of essential oil antifungal activity against mycorrhizal fungi-the case of Laurus nobilis essential oil. Israel Journal of Ecology and Evolution 56(1):35-54. https://doi.org/10.1560/IJEE.56.1.35

Lawrence BM (1983). progress in essential oils: Laurel leaf oil. Parfumer \& Flavorist 8(1):62-65.

Marzouki H, Piras A, Bel Haj Salah K, Medini H, Pivetta T, Bouzid S, ... Falconieri D (2009). Essential oil composition and variability of Laurus nobilis L. growing in Tunisia, comparison and chemometric investigation of different plant organs. Natural Product Research 23(4):343-54. https://doi.org/10.1080/14786410802076200

Mkaddem GM, Romdhane M, Ibrahim H, Ennajar M, Lebrihi A, Mathieu F, Bouajila J (2010). Essential oil of Thymus capitatus Hoff. et Link. from Matmata, Tunisia: gas chromatography-mass spectrometry analysis and antimicrobial and antioxidant activities Journal of Medicinal Food 13(6):1500-1504. https://doi.org/10.1089/jmf.2009.0117

Moghtadar M, Farahmand A (2013). Evaluation of the antibacterial effects of essential oil from the leaves of Laurus nobilis L. in Kerman Province. Journal of Microbiology and Antimicrobials 5(2):13-17. 
Nayak S, Nalabothu P, Sandiford S, Bhogadi V., Adogwa A (2006). Evaluation of wound healing activity of Allamandacathartica. L. and Laurus nobilis. L. extracts on rats. BMC Complementary and Alternative Medicine 6:12. https://doi.org/10.1186/1472-6882-6-12

Özcan M, Chalchat J (2005). Effect of different locations on the chemical composition of essential oils of laurel (Laurus nobilis L.) leaves growing wild in Turkey. Journal of Medicinal Food 8(3):408-411. https://doi.org/10.1089/jmf.2005.8.408

Ozen T, Demirtas I, Aksit H (2011). Determination of antioxidant activities of various extracts and essential oil compositions of Thymus praecox subsp. skorpilii var. skorpilii. Food Chemistry 124:58-64. https://doi.org/10.1016/j.foodchem.2010.05.103

Pino J, Borges P, Ronçal E (1993). The chemical composition of laurel leaf oil from various origins. Nahrung 37:592-595.

Pottier Alapetite G (1979). Flore de la Tunisie. Angiospermes-Dicotylédones-Apétale-Dialypétales. programme flore et végétation Tunisienne Imp. Off. de la Repub. Tunisienne, pp 164.

Quintai L, Yongcheng S (1998). Studies on effect of several plant materials against stored grain insects. In: Zuxun J, Quan L, Yongcheng L, Xianchang T, Lianghua G (Eds). Proceedings of the Seventh International Conference on Storedproduct Protection, 14-19, Bejing PR. China, Vol. 1. Sichuan Publishing House of Science and Technology, Chengdu, P.R. China pp 836-844.

Re R, Pellegrini N, Proteggente A, Pannala A, Yang M, Rice-Evans C (1999). Antioxidant activity applying an improved ABTS radical cation decolorization assay. Free Radical Biology and Medicine 26:1231-1237. https://doi.org/10.1016/s0891-5849(98)00315-3

Saab AM, Tundis R, Loizzo MR, Lampronti I, Borgatti M, Gambari R, ... Menichini F (2012). Antioxidant and antiproliferative activity of Laurus nobilis L. (Lauraceae) leaves and seeds essential oils against K562 human chronic myelogenous leukaemia cells. Natural Product Research 26(18):1741-1745. https://doi.org/10.1080/14786419.2011.608674

Sangun MK, Mahir EA, Karadeniz TH, Caliskan M, Ozkan A (2007). Comparison of chemical composition of the essential oil of Laurus nobilis L. leaves and fruits from different regions of Hatay, Turkey. Journal of Environmental Biology 28(4):731-733.

Sayyah, M, Valizadeh J, Kamalinejad M (2002). Anticonvulsant activity of the leaf essential oil of Laurus nobilis against pentylenetetrazole-andmaximal electroshock-induced seizures. Phytomedicine 9:212-216. https://doi.org/10.1078/0944-7113-00113

Sellami HI, Aidi WW, Bettaieb I, Berrima S, Chahed T, Marzouk B, Limam F (2011). Qualitative and quantitative changes in the essential oil of Laurus nobilis L. leaves as affected by different drying methods. Food Chemistry 126(2):691-697. https://doi.org/10.1016/j.foodchem.2010.11.022

Seyed M, Riaz M, Chaudhary FM (1991). The anti-bacterial activity of the essential oil of the Pakistani Acotus calmus, Callistemon lanceolatus and Laurus nobilis. Pakistan Journal of Sciences and Industrial Research 34:456-458.

Silva MC, Matos AF, Santos HLC, Gomes JV, Pastura DGN, Pereira GL, ... Lima VM (2020). Laurus nobilis L.: assessment of the cytotoxic and genotoxic potential of aqueous extracts by micronucleus and Allium cepa assays. Brazilian Journal of Pharmaceutical Sciences 56:e18302.

Tassell M, Kingston C, Gilroy D, Lehane M, Furey A (2010). Hawthorn (Crataegus spp.) in the treatment of cardiovascular disease Pharmacognosy Review 4(7):32-41. https://doi.org/10.4103/0973-7847.65324

Zargari A (1990). Medicinal plants. Vol. IV. Tehran University press, Tehran pp 325-328.
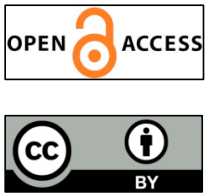

The journal offers free, immediate, and unrestricted access to peer-reviewed research and scholarly work. Users are allowed to read, download, copy, distribute, print, search, or link to the full texts of the articles, or use them for any other lawful purpose, without asking prior permission from the publisher or the author.

License - Articles published in Notulae Botanicae Horti Agrobotanici Cluj-Napoca are Open-Access, distributed under the terms and conditions of the Creative Commons Attribution (CC BY 4.0) License. (c) Articles by the authors; UASVM, Cluj-Napoca, Romania. The journal allows the author(s) to hold the copyright/to retain publishing rights without restriction. 